\title{
DRAMATURGICAL AND THEOLOGICAL ISSUES INVOLVED \\ IN PRODUCING AND STAGING A PLAY IN JERUSALEM ABOUT THE DISPUTATION OF BARCELONA
}

\author{
YAEL VALIER* \\ David Cardozo Academy
}

\begin{abstract}
In the context of the launch of a new theater company whose mission is to bring entertaining theological content to audiences in and around Jerusalem, Roy Doliner's Divine Right was chosen as the company's first production. This play about the Disputation of Barcelona balances historical accuracy and creative dramatic content in a satisfying and intellectually honest portrayal of the events of the Disputation for educated lay audiences. Many theological and dramaturgical issues arise, especially in producing a play with a high level of Christian content and theology for mainly Orthodox or at least traditionally educated Jewish audiences. English speaking audience members in Jerusalem tend to be well-informed, both on the historical level and on the level of Jewish law and mores. This makes them exacting viewers, critical of inaccuracies of history or interpretation, wary of challenging positions but mostly willing to learn, and delighted by thorough research and characterization. This paper examines the technical, dramaturgical, and theological issues that arose during this production for the playwright, director, actors, and audiences.
\end{abstract}

KEYWORDS: Disputation of Barcelona, theater, drama, Orthodox Jews, Jerusalem

\section{Introduction}

In May of 2017, I launched a new theater company in Jerusalem, Theater and Theology, by staging a play about the Disputation of Barcelona. Theater and Theology's mission is to bring thought-provoking theological issues to the public in an entertaining way. I had to choose my first play very carefully. It had to be gripping and grand. After spending time searching for the appropriate play, the play found me. Roy Doliner, playwright and historian, had just moved to Jerusalem from Italy and was looking for a female director for Divine Right. He felt that a female director would recognize that the drama of the play lies in its nuanced portrayal of relationships, with the grander historical drama and intrigues providing the tension and inform-

* YAEL VALIER (MSS 1996, Bryn Mawr College) is the founder and creative director of Theater and Theology and a fellow in the David Cardozo Academy, both in Jerusalem. Email: Yael@TremendousEarth.com. 
ing the action. Though I firmly believe that a male director could be equally capable of a sensitive directing job, I was glad to take on the challenge.

In essence, the decisions I made vis-à-vis Divine Right encapsulate the issues underlying the production of any historical drama: Should the play be limited to as accurate a historical account as possible, or is creative license allowed? Does focusing on the 'smaller' truths of specific relationships and the impact of events on individuals highlight authentic issues that a straight historical account cannot convey to lay audiences? Considering the mission of the theater company, and the need to sell tickets in order to stay afloat financially, is it more the job and moral imperative of the director to educate or to entertain, and to what degree?

Jerusalem contains a highly educated, theologically and academically sophisticated public. The play chosen had to stand up to the public's scrutiny and expertise, and, importantly, to its preconceived attitudes and deeply held beliefs. At the same time, it had to be an exciting, thought-provoking, and nuanced piece of theater.

Thus, the dramaturgical and theological implications of staging a play about the Disputation of Barcelona, particularly in Jerusalem for a mostly educated Jewish audience, are great and delicate. In this paper, I will summarize some of the issues involved, and explain my choice of play and the manner in which I chose to portray it.

\section{Dramaturgical Issues}

\section{Technical Challenges}

The first issue to consider when writing or staging a play about the Disputation of Barcelona is on which version of events to base oneself. For me, and for playwright Roy Doliner, the choice was clear. The terse Latin report of the event is not only sparse in detail, but, on a dramaturgical level, it is far less interesting. Much would have to be invented for lack of primary material, especially in order to realistically portray Nahmanides as incompetent and helpless during the debate. This position would also make it difficult for Jewish audiences familiar with Nahmanides' erudite commentary on the Bible and mastery of the Talmud to suspend disbelief.

Furthermore, all audiences love the ultimate triumph of an underdog, not least an audience that identifies strongly with said underdog-all of which served to make Nahmanides' report the clear choice of document on which to base the drama. Nahmanides' report-without comment on whether it is actually the product of his hand, a retroactively constructed polemic by himself or by others, or a mix of all these things-reads like a screenplay, with large chunks of dialogue already delineated, quotable, and suitably daring and dramatic. 
Choice of venue is an important factor to consider when staging a play. Physical environment influences audience appreciation, even if this is unconscious. Properly, Doliner's play should include many extras cast as noble and plebian onlookers. However, Theater and Theology's format includes a discussion between the audience and a theologian after each performance. Therefore, a small, intimate venue is preferable. This necessarily entails a small stage and, consequently, a limited cast. For me, the small stage at the Jerusalem Khan Theater, built on the ruins of an inn from the Crusader period, was perfect. The naked stone construction of the auditorium, including that providing the back wall of the stage, ensured that the environment was perfect from the moment the audience entered.

As Nina Caputo points out in her fascinating dissection of the process that went into the creation of her graphic novel, Debating Truth, deciding how to physically portray one's characters is a complex issue. Caputo discusses the difficulty of figuring out what, exactly, people wore and how they were groomed in the second half of the 13th century, since 'medieval art was not a literal or realist mode of representation.' For example, she points out that 'Many images of James I that were produced during his lifetime present him as clean-shaven. Beginning in the first quarter of the fourteenth century, though, artists typically represented James I with an impressive beard. Many medieval depictions of kings from this period do include beards, perhaps as a symbol of authority, power, and stability' (Caputo 2016: 202).

In their consideration of the balance between drama and historical accuracy, Nina Caputo and Liz Clarke, her illustrator, generally made decisions that toe the historic line, to the best of their ability. This translated, for example, into their portrayal of James I without a beard. I modeled my James on the famous portrait found on the medieval altarpiece in Palma commemorating his conquest of Valencia. The impetus to do so was dramatic rather than historic. The various portraits of James I with a forked beard make him interesting to look at. As a director, that guided my choice for his character and for the others on stage.

Another example of where Divine Right's characters diverged from the strictly historically accurate for the sake of drama is in the relative ages of Pablo Christiani and Nahmanides. If we accept Jeremy Cohen's assertion that 'probably as early as 1229, when Raymond de Penaforte had preached and missionized in Provence, Pablo converted to Christianity and quickly joined the Order of Preachers' (Cohen 1953: 108), and the assumption that he already had a wife and children at that time, then he was at least close to Nahmanide's age. Doliner, however, deliberately chose to portray Christiani as significantly younger than Nahmanides, and I supported this choice in my casting. The portrayal of Christiani as a younger, charismatic, energetic, 
and confident superstar vs. Nahmanides' apparently tired old-age avoided the need for lengthy exposition through dialogue in order to set up the Church as the obvious favorite in the debate. It also served to make Christiani's ultimate victory-in-name-only a more dramatic failure than if the visual portrayal of the two characters had been more balanced. In commenting on this and other choices, Doliner quotes David Henry Hwang, who claims that a dramatist's job is not to parrot dry information but to tell a 'truer truth'.

In deciding how to dress my characters, I opted to use what director William Ball called 'uniforms'. Uniforms are costumes that include symbols, avoiding the necessity of having to tell a story through lengthy, undramatic dialogue. According to Ball, by 'placing uniforms [on characters], the need for all that dialogue is obviated. It is clear that there are visual symbols in our culture that tell a story without words. A skillful director will have a very creative eye for the possibility of revealing the story through the visual symbols and not relying on the words' (Ball 1984: 150). For Divine Right, for example, the use of uniforms translated into topping the Jewish characters with turbans. Though Jews do not appear to have worn turbans in Barcelona or Gerona in 1263, a turban, closely associated with a famous and completely imaginative 19th century portrait of Moses Maimonides, is a marker for Jews in the mind of Jewish audiences. Therefore, in this case, using turbans was an efficient method of clearly marking the Jews on the stage. Doliner insists that what makes Divine Right interesting, beyond the history lesson and the intellectual sparring involved, is the relationships it portrays. In order to efficiently and indelibly demarcate the opposing 'teams' in the play, I used uniforms, as one does in a sporting event. As such, I dressed Pablo Christiani in the threatening red habit of later Inquisitors, despite this being anachronistic, since the picture this 'uniform' conveys to audience members evokes a familiar and powerful reaction. Though the historic Pablo Christiani did not wear red robes, he was a terrible and potent threat to Nahmanides and to the Jewish community, as symbolized by those robes.

Some of the 'uniforms' in Divine Right were already handed to me by history. The habits of the Dominican and Franciscan friars, for example, which were already distinct in the 13th century, made the sub-plot of rivalry between the Dominican and Franciscan factions throughout the play easy to follow. The antipathy of the white-and-black garbed friars for those in grey, and vice versa, was highlighted for lay audience members who may not have caught on to their different identities and group loyalties by the opinions they expressed alone.

Props and set pieces, of course, are also critical in creating the correct atmosphere for any play. It should not be difficult to obtain set items such as paintings or posters of Jesus, the Madonna, and saints, in Israel. Neither 
should it be difficult to purchase props such as cross pendants. However, for an Israeli who covers her hair in a Jewish-Israeli style and who therefore cannot easily pass for a tourist, this is not necessarily as simple as it may seem. As an Israeli, though the town I live in is basically contiguous with Palestinian controlled Bethlehem, I am not allowed to enter Bethlehem. To do so as an Israeli is to break the law, and to do so as an identifiably religious Israeli Jew is to risk one's life. Obviously, this made shopping in Bethlehem impossible for me. The Arab shuk in the Old City of Jerusalem is the next closest place to seek religious Christian items in my area of the country, but again, especially since I was doing my shopping during the Knifing Intifada, a person who dresses as I do is not untroubled in this setting. According to the Meir Amit Intelligence and Information Center, there were 21 'significant' or substantially violent attacks on Israelis in April and May of 2017 , precisely when I was doing my theater props shopping. Fourteen attacks occurred at the Damascus gate of the Old City-the gate between the Muslim and Christian Quarters-between September 2015 and April of 2017. Nevertheless, I did indeed go through the Arab shuk and to the Christian Quarter of the Old City for prop and set items. Since my spoken Arabic is unexpectedly decent, I had some measure of confidence in doing this. For the theological difficulties of purchasing and using such set items and props, see the Theological Issues section below.

\section{Roy Doliner's Divine Right compared to other historical dramas}

To historically aware Jewish audiences, a story of Jew vs. Hostile Non-Jew, despised vs. favorite, has a mythical quality, with collective resonance and familiar tropes. Jews constantly live these themes from within their scripture, liturgy, and tradition. The Passover Seder, arguably the most widely celebrated Jewish ritual, is completely dedicated to the theme of the triumph of the underdog, through the agency of God, as it recalls and replays Jewish victimhood and redemption. The opposite side of the formula-the failure of the underdog to triumph-has strong roots in the Jewish annual cycle too, with four of the six Jewish fast days dedicated to commemorating destruction and expulsion during and in the aftermath of the first Temple, and one commemorating a failed genocide attempt during the exile in Persia. In short, the collective commemoration of incidents of Jew vs. Hostile Non-Jew in the Jewish tradition boils down to two easy formulae: They tried to kill us-they failed; let's eat! or, They tried to kill us—-they succeeded; let's fast.

The Disputation of Barcelona fits easily into the Jewish psyche as an event of the They tried to kill us—they failed variety, and, in a way similar to Kabuki theater for Japanese audiences or Beijing Opera for Chinese ones, the audience finds comfort, community, and delight in its familiar themes and recognizable tableaux. Jews have been accused of many things over the 
centuries—of being capitalists and communists, misers and profligates, defiant recalcitrants and craven cowards, but never stupid. The picture of a lone Jewish scholar facing down a hostile army of questioners is one that fits neatly into the collective Jewish unconscious, and it is therefore one wellcalculated to draw Jewish audiences to the theater.

Doliner faced many challenges and choices when crafting his play. $\mathrm{He}$ found it necessary to take some dramatic liberties in order to render the story accessible and more theatrical. These include keeping the historic tone of the piece while maintaining its accessibility to the audience, keeping the story flowing, and portraying the now often obscure points of debate in a dramatic, comprehensible, terse, and entertaining manner. To this end, Doliner substituted some of the more obscure points of the debate for current issues still used by missionaries in their efforts to convert Jews.

It is worthwhile noting that Bertolt Brecht and Tom Stoppard faced the same issues when writing their respective plays about Galileo Galilei and his tribulations with the Church. Stoppard, who was hired by Paramount to write a screenplay in 1970 loosely based on Brecht's 1943 play, decided to stick to a more historically accurate, less dramatic account of the life of Galileo. As a result of its lack of panache, Paramount rejected Stoppard's screenplay, and it remained unproduced until it was adapted and played on the Edinburgh Fringe in 2004. Unvarnished history does not usually make for good theater, so a playwright must find a way to highlight themes and attitudes that are true and resonant, without being chained to particular events. For the honest playwright and director, this is a hard balance to maintain.

A play must have substance, tension, drama, and preferably humor, in order to entertain. Hyam Maccoby, a superb academic, wrote The Disputation, a play about the Disputation of Barcelona. Though the play has many qualities, it is less adapted to the sophisticated, religiously, and secularly educated English-speaking audience of Jerusalem. Maccoby's play lacks a certain nuance and substance, rendering it a more appropriate choice, perhaps, for general audiences with no exposure to the times or the topic. $D i$ vine Right's sell-out first and second runs show that Jerusalem audiences enjoy something they can sink their intellectual teeth into.

Beyond the need to keep the story dramatic, Doliner had to keep his audience constantly aware of the mortal danger of the Inquisition. Both Doliner and Maccoby portray the Catholic Church's questioning of Nahmanides as part of the Inquisition, despite the fact that the Spanish Inquisition was only formally established in 1478. The Church in Aragon at the time of James I was influenced by the Medieval Inquisition and the establishment of the Papal Inquisition in 1232. As such, both playwrights refer to King Louis IX of France's political and religious choices as having been 
heavily influenced by the Pope, including his call for the Disputation of Paris in 1240 and the subsequent burning of the Talmud in Paris. Both plays make reference to King James' perception of himself as a candidate for excommunication if he were to defy the Church's desires. And both plays make reference to James' removal of the Bishop of Gerona's tongue and the subsequent pressure applied to the king by the pope in order to have him prove his loyalty to the Church, as the following quotations will show:

\section{Hyam Maccoby's The Disputation, Act I, Scene 2:}

RAYMOND SHOWS A BOX

KING JAMES (admiring box). Nice, eh? The finest ebony wood from Majorca. (Opens box) My, my, the Bishop had a long tongue. Display it in the town square.

RAYMOND DE PENAFORTE. Your Majesty, I must speak openly.

KING JAMES. Please do.

RAYMOND DE PENAFORTE. Pope Urban is outraged.

KING JAMES. The Bishop of Gerona brought it upon himself. He should not have spoken openly against the King.

RAYMOND DE PENAFORTE. He spoke against your infidelities.

KING JAMES. Well he's a mute bishop now, isn't he?

RAYMOND DE PENAFORTE. His Holiness feels that the incident is further proof of your lack of support for the Church. He has recommended your excommunication.

KING JAMES. That would not be good.

RAYMOND DE PENAFORTE. I have been able to delay this while we seek calm. I do think that if the Pope felt that you had more of an interest in converting the Jews to Christianity, so that our Saviour may return, he would be willing to re-examine the penalty.

\section{Hyam Maccoby's The Disputation, Act II, Scene 4:}

RAYMOND DE PENAFORTE TO NAHMANIDES:

The King's position is on a knife edge. Powerful interests wish to dislodge him. His Holiness the Pope is supporting the King at present, but the outcome of the Disputation could affect his attitude. There is strong pressure for Jewish policy in Aragon to conform with that of France. If the King were removed, your position would be very precarious. We have to be able to say that we made at least some progress. We cannot appear weak.

\section{Roy Doliner's Divine Right, Act II, Scene 2:}

In a private conversation, King James explains his position as if he were embroiled in a deadly game of chess: 
KING. Master Moses, do you remember when you taught me the game of Chess? You said there was one secret, and one secret only, and that is: do whatever you must to protect your king. I've followed your rule all these years, and that is why I'm still King. You've heard the tale they tell about me and the former Bishop?

MOSES. No.

KING. You've heard.

MOSES. That rumor about cutting out his tongue?

KING. No rumor.

MOSES. Oh.

KING. Don't look so shocked, my friend. It doesn't befit a man of your years. He was going to have me excommunicated, a condition which makes it fairly difficult for a Catholic king to rule a Catholic country.

MOSES. So, you removed a Bishop to save the King. Where do I fit into this chess game of yours?

KING. Tactical defense. The Church is like that Moorish genie who wouldn't go back in his bottle. Oh, it was easy to raise the banner of the Cross to rally the people, but now, now! This Inquisition, this damned religious furor! It's re-arranged the entire board! Look at Louis; he doesn't rule in France anymore - he bows to the Pope and his holy henchmen. Spain is their next target; this disputation is a test of my strength, not yours.

These quotations show that both Doliner and Maccoby found it important to stress upon their audiences the extreme pressure under which the monarch operated in the face of the Church's power. This emphasis is important for audiences, even those living in relatively religious countries, who exist in a world where their choices as individuals are free, and who need to be exposed to the world of religion-as-dictatorship in order to understand the world of the play.

Apart from substantially sticking to the facts of the trial in order to remain faithful to history, one of the devices Doliner applies in order to maintain the historic tone of the play is the use of highly formal language in relevant court scenes throughout the production. Some of the language is taken straight from translations of Nahmanides' report of events, and some is a pseudo-archaic language of Doliner's own invention that works instantly to immerse viewers in the past, without the need for lengthy expository scenesetting. Divine Right's prologue, quoted below, is an extreme example of this technique, wherein Doliner uses pseudo-biblical language successfully at the very opening of the play in order to make the audience unconsciously aware of the epic nature of the debate and its place in the continuum of Jewish and Church history: 


\section{PROLOGUE}

LEVI: In the Beginning was the Spirit, and the Spirit was given Form, and Religion was created.

GUILLERMO: And from the sands of the Sinai came forth Judaism, and Judaism begat Christianity, and together they begat Islam.

SCHLOMO: And the Kingdom of Israel gave way to the Holy Roman Empire which in turn gave way to the Moorish Empire. And the Religious Powers strove together, each against the other.

RAMON: And Christianity begat the Church which begat the Holy Orders: the Dominicans in their princely white robes and the Franciscans in their common grey robes. And the two orders strove together, each against the other.

GERSHON: And the Church begat also Dogma and Dogma begat Heresy and Heresy begat-the Inquisition. And Terror and Suffering covered the face of Europe.

TOMAS: And during these Dark Ages, in the middle of the ill-favored Thirteenth Century, all these forces were brought together, to a palace in Barcelona.

JEW (YITZCHAK): And there, for four days, they all strove together, each against the other.

END OF PROLOGUE

In choosing which points of the original debate to feature in their plays, and which to cut or substitute, both Maccoby and Doliner had to keep in mind what would be accessible to the average viewer. Maccoby addresses the problem by cutting down heavily on substance, though he, like Doliner, does make reference to Nahmanides' own report of the debate for material. Maccoby's debate scenes are shorter and simpler than Doliner's, and the details of the debate are curtailed, with points of dispute rarely going through more than a few iterations of questioning and answering. Furthermore, in Maccoby's play, issues are debated more as theoretical positions, with scant reference to sources, rather than as the result of the examination of the minutia of Scripture or the Jewish Oral Tradition. Doliner's play gives the audience a taste of the convoluted nature of the debate and the erudition and preparedness of the interlocutors in a series of sustained bouts in which sources in Scripture and the oral tradition are constantly quoted.

When quoting sources, Doliner had to decide how anachronistic he could allow himself to be. The division of the Bible into verses within chapters was only imposed on the Hebrew Bible by the Catholic Church in 1571. However, modern audiences are used to hearing chapter and verse quoted. 
In response to this, Doliner uses verse and chapter numbers in his play. Maccoby avoided the anachronism by referring only to 'the Talmud' or 'the Bible'.

In Jerusalem, I would not be able to get away with vague references to 'the Talmud' in situations where, in fact, the text debated is not included in the Talmud, but rather lies in other books in the oral tradition. In the first read-through of Divine Right with the actors, three of the actors immediately spotted and objected to an incorrect quotation! Doliner had written that something was from 'Talmud, Commentary on Hosea, 518.' This was perfectly acceptable and sufficient for the general audiences for whom Doliner was originally writing. However, a Jerusalem audience holds viewers who would immediately spot, and be bothered by, the inconsistency. The actors in my cast recognized the quote as coming from the Yalkut Shimoni, a nonTalmudic compilation of aggadic writings on the books of the Bible, and immediately went looking for the exact source, so as to quote correctly on stage. Doliner approved their request to change the line, and compromised with 'Yalkut Parables on Hosea, 518'. (I will address the peculiarities of my cast in the Theological Issues section, below.)

Nahmanides' own report of the debate, polemical in nature, provides much natural drama in the form of Nahmanides' outrageous, daring (or foolhardy), and shocking pronouncements. Doliner makes full use of these in his play, and I will discuss the difficulty of staging them effectively below. Maccoby chose to do so much less frequently, often leaving out Nahmanides' scandalous pronouncements. Perhaps Maccoby feared that no audience could accept the authenticity of Nahmanides' more outrageous assertions in a hostile court - a reasonable assumption. Doliner included them-another fact that encouraged me to produce his play. Though I suspected that a percentage of my audience would doubt the veracity of these episodes, I also knew that they would relish them. Additionally, the format of Theater and Theology always includes a talk-back session after the performance, in which a Jewish or Christian scholar discusses the play and answers questions. This allows my audiences to voice their doubts and to have them be confirmed or denied. And indeed, most nights, a member of the audience asked Doliner (who was always present) and the scholar if Nahmanides could possibly have said all those outrageous things. The talkback format gives me more creative freedom as a director, since I know that historical inaccuracies and anachronisms will be addressed by the end of the evening.

Below, I have reproduced one passage from each play that illustrates Maccoby's and Doliner's different methods of handling both source quotations and Nahmanides' self-reported daring assertions, in this case his asser- 
tions about the difference between the Messiah's being born and his 'coming'.

\section{Hyam Maccoby's The Disputation, Act I, Scene 6:}

PABLO CHRISTIANI. Your Majesty, let me cite a passage not from the Old Testament but from the Talmud. The Talmud says, 'At the time when the Temple was destroyed, the Messiah was born.' ...Let me put the question directly to Rabbi Moses. Why are the Jews waiting for the Messiah when their own Talmud tells them that He came twelve hundred years ago?

KING JAMES. What have you to say to this, Rabbi Moses?

MOSES BEN NACHMAN. Your Majesty, with respect to Brother Pablo, the Talmud does not say that the Messiah came at the time of the destruction of the Temple. It only says that He was born then.

KING JAMES. That's more or less the same, no?

MOSES BEN NACHMAN. No, your Majesty. When Moses was born he did not immediately lead the children of Israel out of Egypt. That was hardly a task for a new born babe. The event itself took place eighty years later. Similarly, the date of the Messiah's birth is by no means the same as the date of His coming.

KING JAMES. And when will be His coming?

MOSES BEN NACHMAN. When he leads the Jews back to the Holy Land. That hasn't happened yet so he hasn't yet come.

\section{Roy Doliner's Divine Right, Act II, Scene 2:}

PABLO: ... Behold, I quote from the Commentaries on Lamentations, Chapter I, paragraph 57, where the story indicates that the Messiah was born at the same moment that the Holy Temple was destroyed.

MOSES: Paragraph 57? This is truly preposterous! Out of all the laws, the wisdom of the Talmud, you choose a parable, an obscure legend which I don't even believe word for word!

PABLO:isepin, I am preposterous! See how this Jewish Master denies the holy writings of his own people!

MOSES: Yes! Yes, I do! These are writings of men-wise men, holy men, but men nonetheless - and I am not bound to swallow their every word as Gospel truth.

PABLO: But here, word for word, your precious Sages say the Messiah has come!

KING: Answer the question.

MOSES: As you wish. The Sages in this legend do not say that the Messiah has come, but only that he was born. On the day that my namesake, Moses, was born-peace be with him-he was not yet our deliv- 
erer; he had not yet come. It was not until he came to Pharaoh by the command of G-d and said, 'Thus saith the Lord: Let My People go!'- then he had come. David was born a mere shepherd boy, but when Samuel anointed him King of Israel, then he had come. And so it is with the Messiah. Only on the day when the prophet Elijah anoints him will he rightly be called 'Messiah', and not before. And on the great day when he goes to Rome, to your Pope by the command of G-d and says: 'Thus saith the Lord, Let My People go!', then-then I will be the first to proclaim to the world: 'Yes, it is true! Yes, at last, it is the Messiah! Behold, the Messiah has come!'

From the quotations above, it is clear that Doliner was willing to rely heavily on Nahmanides' report and to quote it, where appropriate, in its complexity and daring. This makes for excellent theater!

In Maccoby's play, Nahmanides is always the cleverer combatant, and the king assures Nahmanides before the debate begins, that whatever the result, he guarantees safety for Nahmanides' family and community, hence destroying in advance any tension the audience might have experienced in their fear for the fate of Nahmanides. Doliner maintains drama by portraying the high level of debate on both sides, thereby generating tension in viewers who do not know in advance whether Nahmanides will win or lose any particular battle within the war. In Act I of Doliner's play, Nahmanides loses the first day's debate, whereupon his family gathers to lick its wounds and prepare for the next day's bout. This is excellent dramatic technique, as well as an effective vehicle for accurately portraying the Church as a formidable opponent-not just because of its power, but also thanks to its erudition.

Doliner also introduces and maintains drama by featuring the rivalry of the Franciscans and the Dominicans in his play. Maccoby makes brief mention of this rivalry, but Divine Right uses it extensively to advance a more nuanced understanding of the Church in the 13th century. Doliner wanted to show that there was a history of cooperation and shared scholarship between Jews and Christians, and that there existed voices in the Church that called for a genuine search for truth. (This is consistent with Doliner's position and ideals as a lecturer for the Center for Jewish-Christian Understanding and Cooperation in Jerusalem.) Doliner uses the character of a Franciscan monk, whom he calls Tomas, as the mouthpiece for this stance. Tomas' character arc has him begin the play as equally contemptuous of Nahmanides as all the other friars, and end the play with deep respect for Nahmanides. In Tomas' words, 'How can I hear a man speak like that and call it ignorance? How can I witness faith like that and call it arrogance or blasphemy?' Doliner based the character of Tomas on Brother Peire of Ge- 
rona, who made one comment on Nahmanides' behalf in the original Disputation, according to Nahmanides' own report. Brother Peire hastily withdrew his support immediately upon Nahmanides' declaration that his comment supported the Jewish claim. Maccoby, in Judaism on Trial, explains this incident in a footnote as follows, 'Fray Peire de Gerona: He was of the Franciscan Order, and some have seen in his intervention here on N.'s side an indication of the rivalry between Franciscans and Dominicans... Later the same Peire de Gerona took a leading part in the move to suspend the Disputation... and again, he hastily withdrew, as here, when his support for N. became embarrassing' (Maccoby 1982: 108). Doliner changed Brother Peire's name to Tomas for the sake of any audience members who could catch the reference to 'Doubting Thomas', the skeptical apostle. In Doliner's play, Tomas earns the name by refusing to sustain a position that contradicts the evidence of his own eyes: the fact that Nahmanides is a respectworthy man. The developing story makes it clear, too, that Nahmanides returns Tomas' respect, and it is certainly Doliner's ulterior motive in developing this story arc to show that Christians and Jews can live with mutual respect and a shared desire to learn from each other.

Doliner also uses the tension between the Franciscan and Dominican friars to further illustrate the power and danger of the Inquisition, not only vis-à-vis Jews, but chiefly vis-à-vis Christian heretics. In Act II, Scene 4, in a scene where Nahmanides becomes weak from the stress of the trial, we see the following exchange between the Franciscan Father Tomas, and Pablo Christiani:

TOMAS: Your Majesty_perhaps Master Moses would like to rest, after all.

PABLO: Perhaps Father Tomas would like to take his place. Take care, for the Inquisition is here to judge not only the Jews, but Christian souls as well. Now, what were you saying?

TOMAS: Nothing... nothing at all.

PABLO: As I thought. Master Moses, can you answer? Or do you concede?

Compare this scene to a similar one, written by Jean Anouilh in his play L'alouette, about Joan of Arc. Like Doliner, Anouilh must show his audience, without resorting to boring exposition, that the Church is all-powerful and keeps rigid discipline in its own ranks. In a scene in which L'Advenu shows some sympathy for Joan's defense against the Church, L'Inquisiteur snaps back, 'Silence, Frere L'Advenu, vous di-je! Ou il faudra que je m'occupe aussi de votre cas' (Anouilh 1972: 128). As in Doliner's play, this threat does its work of silencing the offender. Both playwrights effectively use this ele- 
gant device, basing their writing on history while allowing themselves to imagine a scene designed to bring understanding, if not literal reality, to the audience.

The more balanced portrayal of the Church provided by the character of Tomas in Divine Right was a further draw for me as a director. Despite his need to show the puissance and threat of the Church, Doliner succeeded in avoiding a crude 'Defendant good, Church bad!' message in which other playwrights indulge. It is always easy to make fun of the Church, as Jerome Lawrence and Robert E. Lee, for example, do in their 1955 play Inherit the Wind about the famous 1925 Scopes 'Monkey Trial', convened to try John Scopes for teaching evolution to his high school science class. In its zeal to apply its metaphor against McCarthyism, the play distorts history so much as to do the citizens of Tennessee and the Church a disservice. Lawrence and Lee's play makes excellent theater, but the Church pays heavily in collateral damage. Divine Right, on the other hand, avoids this playwright's trap by making excellent theater without resorting to the easy besmirching of an entire institution-a much more difficult accomplishment.

\section{Theological Issues}

Before they even buy a ticket, Jewish audiences are highly invested in the outcome of any play featuring controversy between Christians and Jews. For Jewish audiences, this is not just an interesting play about a past event. In the Jewish psyche, medieval disputation is simply another event in a continuous line of trials, persecutions, expulsions, missionizing, book-burnings, and pogroms. Jewish practice keeps ancient events fresh. As mentioned above, the Passover Seder recalls the Exodus from Egypt with great drama and ceremony, keeping this seminal event very much alive in the Jewish consciousness. The order of the Seder includes a passage that explains the Jewish position on persecution: 'And this is [the divine promise] that maintained us and our fathers, for not only one [persecutor] stood against us to annihilate us, but rather in every generation they stand against us to annihilate us, and the Holy One, blessed be He, preserves us from their hands' (Traditional Passover Haggada, my free translation). This passage of the divine promise, written about 1,600 years ago and set to new music, became an Israeli hit song in 2009, when the Israeli psyche was still reeling from the violence of the Second Intifada, and in particular from the horrendous terrorist attack on a high school in 2008. In Israel, the ancient and the modern are inseparable.

At fixed times every year, Jews say the Merciful Father prayer for people who were killed in the Holocaust, in pogroms, and during the Crusades. They also recite laments on certain fast days for these events and for the destruction of the First and Second Temples. In other words, for Jews, the past is part of a continuous present. Furthermore, Jewish prayer, ancient and modern, relates to space in the same way that it relates to time. There is 
no difference to traditional Jews between Diaspora Jews and Israeli Jews, and they plead for both. Jews are Jews, undifferentiated by country of residence.

All of this is to say that the fact that the Disputation of Barcelona occurred close to 800 years ago, in Spain, does not cushion modern Israeli audiences from its tension and menace. In his 2009 doctoral dissertation, Milan Zonka discusses this phenomenon. He claims that Yitzhak Baer's evaluation of the Disputation and its primary texts stem 'from Baer's antagonistic notion of medieval Jewish-Christian relations and his 'lachrymose' view of Jewish history, in which every interreligious confrontation represents another battle in the historical war for Jewish survival, [rather] than from a reasoned evaluation of the event itself' (Zonka 2009: 20). Zonka may be right, but Baer's conception is a good description of that of my educated, religiously-involved Jerusalem audiences too.

So, due to their religious consciousness and training, my audiences need to see a play that ultimately shows a Jewish triumph, but due to their scholarship and sophistication, they also need to see a play that arrives at that triumph via a balanced and nuanced approach.

Jewish law includes injunctions that make staging a play about the Disputation difficult, both for Orthodox Jewish actors and for Orthodox Jewish audiences. Although there are always different interpretations of the law, a fundamental Jewish distaste for anything that could smack of idolatry remains. Jewish law debates whether Christian belief constitutes idol worship or not. There are opinions on both sides, relating to the Jewish difficulty in relating to the belief in a triune God. Rabbi Moses ben Maimon (Maimonides), born in Cordoba in the 12th century, takes a conservative position, considering Christianity equal to idolatry based on his perception that Christians believe in a God who is not One. In his major compendium of Jewish law, Maimonides writes, 'It is forbidden to enter a church or an idolatrous temple' (Maimonides 1990: AZ:1). The 13th-century Rabbi Menachem haMeiri from Catalonia takes a counter position in his work Beit HaBehirah. In the section of his commentary on the Talmudic tractate Avodah Zarah, he argues that the majority of the laws against idolatry and against fraternizing with idol worshippers do not apply to Christians because Christians are 'restricted by the ways of religion', and their religion is one that urges them to use their free will and to live meritoriously (Meiri 1969: 53). Many Modern Orthodox Jews hold a liberal position vis-à-vis Christianity, but the Maimonidean position continues to pervade the Jewish consciousness as well.

Though volumes have been written on this topic, I will restrict myself to three laws quoted by three different Jewish scholars as further examples of scholarship dealing with the Jewish relation to Christianity: 
Rabbi Yosef Karo, author of the Shulchan Aruch, the seminal Code of Jewish Law written from the Sephardic perspective and published in 1565 in Venice writes, 'There is no prohibition against owning idolatrous figures. However, there is a prohibition against gazing at such figures, which would in general prevent one from owning them. It is permitted to gaze at an idolatrous figure that is not intended for the purpose of worship' (Karo 1977: YD 141:1).

Also in the 16th century, Rabbi Moses Isserles added a gloss to the Shulchan Aruch, based on the Ashkenazic tradition. He includes a comment on the law above, claiming that a cross constitutes an idolatrous figure, but in circumstances in which worship is not intended, such as a pendant on a necklace, it is permitted (Isserles 1977: YD 141:1-3).

Rabbi Shlomo Ganzfried from Hungary published the Kitzur Shulchan Aruch in 1874. It is a summary of the Shulchan Aruch but it also refers to later commentators. He writes, 'It is forbidden to utter the name of an idol, whether for some purpose-such as to tell a friend, "Wait for me next to such-and-such idol"- or whether it is for no reason at all, as per Exodus 23:13, "Do not mention the name of other gods"' (Ganzfried 1991: 167:12).

All of these laws are based on previous scholarship, which itself is based on an understanding of biblical text. Regardless of whether all members of modern Israeli Jewish audiences subscribe to these laws or are even aware of them in particular, history, Jewish law, and the milieu in which it was forged have created a society with a strong visceral reaction to Christian icons and modes of worship. Furthermore, where Christian audiences react in one way to, say, a portrait of Jesus on the Cross, Jewish audiences react differently. To Christian audiences, a portrait of Jesus is a portrait of Love. A portrait of Jesus inspires notions of mercy, grace, forgiveness, and compassion. To many traditional Jews, depictions of Jesus or a crucifix evoke cultural memories and a latent fear of persecution, blood-libel, oppression, and death. Divine Right makes reference to this phenomenon in Act II, Scene 1, in a dramatic night-time scene in which one of the sons of Nahmanides engages in a heated argument with the king's justiciary in the deserted courtroom:

GERSHON: Ahhh, there's something you know about, isn't it? Killing, thieving, spreading hate-that's all right, isn't it, as long as you can trot back to your church and bow down to a statue or (pointing to a crucifix) that symbol of Roman torture and say you did it all in the name of your savior!

Many of the English-speaking actors in and around Jerusalem are Orthodox Jews. Those that are not are often learned in Jewish practice and culture. Four of the thirteen actors in my cast have rabbinic ordination! Some of my actors, steeped in consciousness of the laws, injunctions, and debates 
quoted above, refused to wear a cross as part of their costume, though one was willing to consider wearing a Franciscan Tau. Some of my actors refused to shave off their beards. Some of my actors refused to kneel or to make the sign of the cross, as it is so strongly ingrained in them that these actions are forbidden. Whether doing so for the sake of a stage play could be permitted, as some of the legal opinions I quote above imply, is irrelevant; it feels forbidden. Some of my actors were not willing to intone the Pater Noster. All of this, even though it is clear that these actions in no way represent the true feelings of the actors. (One of the actors asked me to add a blurb in the playbill making it explicit that the opinions he espouses on stage do not represent his true opinions.) I was expecting this and, in the interests of getting the best actors I could as well as in deference to my own tradition (I am an Orthodox Jew), I told all my auditionees that I would work around their objections. As a result, I staged the play so that only one actor kneels, though that actor does not make the sign of the cross, and only one actor crosses himself (though he refused to kneel!). Some of my actors asked to change some references to 'Jesus Christ' in the play to simply 'Jesus'. They objected in deference to the opinion, quoted above, that it is forbidden to mention the name of other gods, and in acknowledgement that 'Christ' means 'anointed'-therefore implying that Jesus was indeed the Messiah. It should be noted that some of my actors expressed no objection whatsoever to any of the above issues.

Some potential audience members, too, expressed a reluctance to buy tickets for a play whose set includes large Christian icons. The publicity posters for Divine Right, which included a photo of Pablo Christiani wearing a cross, were taken down in some conservative Orthodox neighborhoods. As a result, two other poster versions were printed. One simply left out the crosses, and one, printed for a special performance in an Orthodox neighborhood community center outside of Jerusalem, included the following blurb: 'The set includes large Christian icons. The Ramban and the Jews of Barcelona were surrounded by these, and the discomfort they create in us is a reflection of the discomfort they suffered.' This blurb was a compromise I negotiated with the director of the community center, who refused to promote the play without it.

It should be emphasized that there are plenty of communities and theater groups in Israel-the overwhelming majority-where none of this would be a problem. The goal of Theater and Theology, though, is to bring thought-provoking theological material to scholarly audiences who seek education along with their entertainment. This particular niche draws religiously and culturally aware audiences, particularly in Jerusalem, where Theater and Theology is based. 
The difficulties I faced in producing Divine Right are not exclusive to me or to Theater and Theology. Other Orthodox playwrights and producers who are interested in creating educational, theologically relevant theater face the same issues. Two modern English-speaking Israeli playwrights, Sharon Katz and Avital Macales, recently wrote Hidden, a musical about a family of conversos in Spain in the 1700s. Hidden was produced by the Women's Performance Community (WPC), an Orthodox theater company comprising female-only casts who perform for female-only audiences for reasons of modesty. Katz and Macales made far more conservative decisions than I did, based on the sensitivities of their Orthodox/Ultra-Orthodox audiences. While trying to project a picture of the Christian community that is not a caricature, but deliberately not as nuanced as Doliner's, they decided to avoid all representations of crosses, icons, and statues, in deference to the laws and mores I quote above. Katz and Macales invented the prayers in their play, in consonance with a strict understanding of the Jewish prohibition against intoning the prayers of another religion and of mentioning the name of foreign gods, whereby none of the prayers in their show make mention of the Son or the Holy Spirit. They felt they had to write the content of the prayers to be consistent with what any Jew would feel comfortable saying. Though Katz and Macales had actors costumed as friars, the prayers the actors chanted only involved sounds, like 'aaah', and the occasional neutral word, such as 'Hallelujah'. According to Macales, whom I interviewed while she and Katz were still writing the musical, 'If we put actual words to a tune and have people dressed as monks singing, the visual will be too strong. We need to avoid giving the impression that the people on stage are actually chanting a Christian prayer. The audience would not appreciate the realism. They'd be uncomfortable. The only way they can allow themselves to see this show is by knowing that they won't encounter any strongly religious Christian portrayals. They would never go to see a show on this topic written by a secular playwright. I have had to invent 'Christian' prayers for small children to say. I came up with something like, 'I thank Thee for the day that you have given me, and I plead with You to deliver me from sin'. [The focus on sin seems solidly Christian to me, and it still answers the requirement of being authentically Jewish too.) Orthodox child actors are going to say these lines. What are their parents going to say? Mom, can you help me with my lines? I'm very nervous about this' (Macales 2017, personal interview).]

Beyond the difficulties I faced in convincing some of my actors to act overtly Christian on an overtly Christian set, and the difficulties I faced in convincing my target audience to attend such an event, even though my target audience is not as conservative as Macales and Katz's, I also faced difficulties in training my Jewish actors to understand the philosophies that 
would shock and offend devout medieval Christians. In order for Jewish audiences to understand the volley of proofs and insinuations during the debate, and to understand the sensitivities, courage, and danger involved, they must comprehend the implications of the interlocutors' pronouncements. Divine Right is actually a much more balanced play than Jews or Christians tend to realize; since committed Jews and Christians recognize and resonate with their own arguments and positions, and tend to unconsciously dismiss the opposing position as irrelevant, they remain immune to arguments that pose a genuine challenge to their respective orthodoxies.

A good example of the above phenomenon is a speech by Pablo Christiani to Father Tomas in Act I, Scene 2 of Divine Right in which he tries to explain the wicked stubbornness of the Jews:

[They are] So smug, so all-knowing... you look at them and their lives and call it faith? That's not faith-it's dull habit, like that of an unthinking pack animal plowing the same row, year after year. They can only look down, their shoulders are so bent under the yoke they wear, the heavy yoke of their Law. But will they shrug it off, even for a moment of freedom? Never! No, they cling desperately to their familiar burden, they refuse to look up even for an instant; they refuse to see the new Light shining down on them from Heaven.

The above is a legitimate criticism of Judaism that should not be dismissed without consideration, but it tends not to resonate with Jewish audiences, who might dismiss it rather than be inspired to consider its implications. The same is true of Christian audience members who may unconsciously dismiss powerful Jewish arguments before examining them in any way.

Hence, it is critical that the actors playing Christians inform the mostly Jewish audience, through their expressions and reactions, of what would have been outrageous and offensive to the Christians in King James' court, and to convincingly render the power of reasonable Christian arguments by showing the discomfort on the face of the Jewish onlookers who hear them. The audience needs these cues to keep it aware of and focused on the various heresies on both sides-the problem is that it is difficult for actors to react to heresy if they do not recognize it!

For example, in Doliner's play, as in the report of Nahmanides himself, Nahmanides tells the king in Act 1, Scene 2, 'My lord, you are worth more to me than the Messiah. You are a Gentile king and he is a Jewish one, but the Messiah in our religion in only a king of flesh and blood like you. I do not live my life in hope of his salvation. What is important to me, as it is to any Jew, is what I do here and now to earn it myself.' Of course, this was a shocking statement for the Christian onlookers who attended the Disputation, but to my Jewish actors, it is entirely in keeping with their philosophy, and therefore something to which they would tend to react with a slight 
nod. In this case and in many others, I had to work with my actors to ensure that they reacted to the pronouncement with the appropriate level of shock and disgust. This work involved reading the play slowly through and discussing the implications of each round of challenge-and-response for the Christian side and the Jewish one. My actors did not have any trouble understanding the Christian point of view once it was taught to them, but they did have trouble staying in character when acting as observers to the proceedings. They needed constant reminding that they were portraying observers steeped in Christian philosophy. Had my actors been religiously indifferent, it would have been easier for them to stay in character, but for these religiously and culturally aware Jewish actors, it was hard to shake the habit of listening like a Jew.

Doliner includes an epilogue in Divine Right in which the actors fill in for the audience the fates of the various characters after the events described. Similarly to the prologue, the epilogue has actors tell the story while no longer in character. For dramatic effect, and in order to help audiences who may have felt uncomfortable seeing Jews wearing a different religion's symbols, I have the actors de-role as they speak their lines during the epilogue. This device culminates in the actor playing Pablo Christiani taking off his zucchetto and cross pendant as he says his lines. Taking off these religious symbols makes the Jewish and Christian characters look more similar-a fitting prelude to the last line of the epilogue, spoken by Nahmanides:

'And God, what happened to God? Oh, the Supreme Judge still sits on the Heavenly Throne. And as God watches us dispute His Name through the ages, He sheds a tear and says: "How long, O Man? How long?"”

\section{Acknowledgments}

I am grateful to Roy Doliner, playwright of Divine Right, and Avital Macales, co-playwright of Hidden, for agreeing to be interviewed for this paper. I am also grateful to Dr. Hannah Davidson, medievalist and author of the article HaRamban Veha'aggada Beheksher Vikuah Bartzelona (Nahmanides and Aggadah in the Context of the Disputation of Barcelona), for her advice throughout the production of Divine Right and for her help in locating sources for this paper.

\section{Bibliography}

Anouilh J (1972) L'alouette. Paris: La Table Ronde.

Ball W (1984) A Sense of Direction: Some Observations on the Art of Directing.

New York: Drama Book Publishers.

Caputo N and Clarke L (2016), Debating Truth. The Barcelona Disputation of 1263, A Graphic History. Oxford: Oxford University Press. 
Cohen J (1982) The Friars and the Jews: The Evolution of Medieval Anti-Judaism. Ithaca-London: Cornell University Press.

Doliner R (1985) Divine Right. Unpublished. Copyright registered in Library of Congress.

Ganzfried S (1991) Kitzur Shulchan Aruch. In Kitzur Shulchon Oruch. Jerusalem: Moznaim Publishing Corporation.

Isserles M (1977) Hagaot HaRama. In Shulhan Aruch. Jerusalem: TalMan.

Karo J (1977) Shulhan Aruch. Jerusalem: TalMan.

Maccoby H (1982) Judaism on Trial: Jewish-Christian Disputations in the Middle Ages. London: Associated University Press.

Maccoby H (2001) The Disputation. London: Calder Publications Ltd.

Maimonides M (1990) Mishna Torah. Jerusalem: Moznaim.

Meiri M (1969) Beit HaBehira. Jerusalem: Isaak Lang.

Zonka M (2009) Authority and Apostasy: The Barcelona Disputation in the Context of Thirteenth-Century Jewish-Christian Polemics. PhD Thesis, Karlova v Praze University, Czech Republic. 